\title{
CHALLENGES AND PROPOSED MODEL IN IMPLEMENTING INTEGRATED MEDICAL RECORD SYSTEMS IN INDONESIA
}

\author{
Andi W.R. Emanuel* \\ Magister Teknik Informatika, Universitas Atma Jaya Yogyakarta, Indonesia \\ andi.emanuel@uajy.ac.id
}

\begin{abstract}
Indonesia is a nation with the fourth largest population in the world with unevenly distributed in five major islands and other 17,000 islands. The medical services are provided by the Centre of Community Health (Puskesmas), Clinics, and Hospitals that are mostly using their own implementation of Electronic Medical Records, which are incompatible and inconsistent. Integrating these Medical Records poses a lot of challenges, but the recent improvement in Information Technologies may solve this problem. This research presents challenges in providing integrated Medical Record Systems and proposed solutions to the problems based on the recent improvement in IT such as NoSQL database, SymmetricDS database replication, OAUTH2 authentication server, REST web service, etc. These proposed solutions may provide initial steps in providing integrated healthcare solutions to entire population of Indonesia by the Ministry of Health.
\end{abstract}

Keywords - Integrated Medical Record Systems, Healthcare, Medical Services, Indonesia

\section{INTRODUCTION}

Indonesia is the largest archipelago country in the world with a large number of populations. With the number of populations reaching the fourth in the world but most of the population is concentrated in java and other large islands, providing enough healthcare for all of Indonesian citizens in more than 17,000 islands poses many challenges, more specifically in medical services. Medical services in Indonesia are carried out by many types of medical facilities such as the Centre of Community Health (Pusat Kesehatan Masyarakat or Puskesmas), health clinics, and many types of hospitals under the coordination and regulation from the Ministry of Health. The backbone for medical services in all medical facilities is the existence of medical records. The Ministry of Health obligates every health facility to have medical records for their patients with certain information recorded into them. However, in practice the data collected by many medical facilities in Indonesia are incompatible and inconsistent.

The standardization of the format of Electronic Medical Records has never been legalized which makes the integration of these records almost impossible. The Ministry of Health has made regulation regarding Medical Records with no detailed specifications for the electronic or digital format which makes each of the medical facilities make their own interpretation of the medical format for their own purposes. This condition will make patients transfer from one medical facility to another is based on printed resume of medical records which can be easily lost and provide imprecise information. This will also present

Received: June 1, 2019

Reviewed: August 21, 2019

Accepted: September 1, 2019

* Corresponding Author 
difficulties for patients since he/she must remember all his / her medical histories when coming to a new medical facility. The facilities may also not fully belief or if the patient will lie with the story from the patients so they will require their patients to undergo thorough lab examination at his / her patients' expenses and present additional time to wait before getting proper medical treatment. With the lack of coverage in medical records, medical services may not be provided in holistically manner. Patients will find their own solution for their medical problems by using alternative medications, buying restricted medication without doctor prescription. They also may use other solutions such as using traditional medical expertise and so on. Indonesia should have an integrated healthcare system based on integrated medical record systems that may provide holistic, effective and efficient healthcare services to its citizens.

\section{LITERATURE REVIEWS}

Healthcare for the citizens of Indonesia is regulated by the governing body which is the Ministry of Health (http://depkes.go.id). The main task of the ministry is to determine the national, operational, and technical policies in healthcare. Some of the important functions of the ministry are determining the national health policy, minimum health services, build a national health plan, and information system health policy [1]. Some of the policies including the medical facilities and medical records.

There are several types of medical facilities in Indonesia based regulation released by the Ministry of Health (Permenkes 340/MENKES/PER/III/2010). Hospital Type A is the largest type of hospital with many services for specialty and sub-specialty. Hospital Type B has many services for specialty and limited number of sub-specialties. Hospital Type C offers limited sub-specialty services and specialty only for internist, surgery, child health, maternity. Hospital type D only offers limited speciality such as general health or dental health. There are also private and specialty hospitals. In the lower types of facilities such as Pratama Clinic, Primary Clinic, and Clinics owned by the Army and Police. The grassroot health facilities are called Puskesmas or Centre of Community Health which is divided by the facilities that offer inpatient and outpatient, or outpatient only. In addition, some of the doctors may also offer their medical practices in their own homes or other locations.

Medical Record in Indonesia is also regulated by the Minister of Health (Permenkes 269/MENKES/PER/III/2008) which is mostly for non-electronic medical records. The medical record is categorized into three types which are for inpatient, outpatient, and emergency patients. The main fields of the medical records for outpatient are patient identity, time and date, anamnesis result, physical examination, diagnostic, plan for care, medication, other services, clinical ordontogram (form dental patients), and agreement for further actions. The fields for inpatient are similar for outpatient with additional fields for notes for clinical observations, discharge summary, names of doctor/dentist/paramedics. Finally, emergency patients have fields like outpatients will additional fields such as the patient condition when arrived at the facility, a summary of patient conditions after leaving facility, transportation when transferred to another facility.

There are some regulations regarding Medical Records and Medicare in Indonesia. Act number 36 the year 2009 about Health. Act number 8 in year 1999 about Consumer Protection. Act number 29 in year 2004 about Medical Practises especially in article 52 about Patient Rights. Act number 40 in year 2004 about National Social Security System. Act number 44 in year 2009 about Hospital especially article 32 about Patient Rights. Act number 24 in year 2011 about Governing Board of Social Security. Act number 38 in year 2014 about Paramedics. Department of Health also has Strategic Plan 2015 - 2019. Presidential Regulation number 82 in year 2018 about Healthcare. Health Minister Regulation (Permenkes) number 269/MENKES/PER/III/2008 about Medical Record. Health Minister Regulation (Permenkes) number 1172/MENKES/PER/VI/2011 about Hospital Information System. 
There exist BPJS (Regulating Board for Social Security) which act as national-wide health insurance company for the entire nation of Indonesia, but this organization still has many weaknesses and problems. BPJS is founded based on Act number 40 the year 2004 about National Healthcare Assurance, BPJS is founded based on Act number 24 the year 2011 which replace the existing National Healthcare Network (JKN). The budget for BPJS is always growing and it causes many problems. The BPJS still owes large amount of debt from many hospitals.

Indonesian Healthcare system should be integrated in the year 2019 [2], but most hospitals are not yet implementing integrated medical record system [3] and even some medical facilities are still using manual (paper-based) system. Centre of Community Health or Puskesmas is obligated to have printed version of medical records and keep them for at least 10 years, they also may have electronic medical information systems that are provided by many vendors without any standardization of the medical record format. Department of Health in the districts where Puskesmas is located also imposes its own version of medical format. For hospitals or other medical facilities that have some types of medical information systems especially electronic Medical Records, they develop their own interpretation for medical records which may be completely different from one another since there is no regulation about the electronic version of Medical Records.

The implementation of Hospital Medical Information System in Indonesia is also the subject of many research, but the research regarding the integration of medical data in Indonesia is still limited. The document format of the Medical Records is discussed such as in CORBA [4]. The study of Hospital Information System such as the study of the usage of such system in the Special Region of Yogyakarta [5], using HOT-Fit approaches [6], implementing Total Architecture Synthesis [7], using open source technologies [8], using expert system for mental health services [9], system for medicine supplies using Apriori [10], building Datawarehouse [11], e-CRM [12], and Geographical Information System in Special Region of Yogyakarta [13]. Regarding integration of medical data, some researches already acknowledge that there are many challenges in integrating Medical Records in Indonesia. Braa et. al. proposes the use of CAS (Complex Adaptive System) to address the complexity in integrating many health records in Indonesia [14].

This research is the continuation of previous research [15] about the replication of Medical Records in hospitals with a similar system. Challenges in integrating the Medical Records from many health facilities in Indonesia are presented and some initial solution is proposed towards integrating them.

\section{RESEARCH METHODOLOGY}

This research is qualitative research which is based on observation and interviews. The first step is literature reviews based on papers in the field of Hospital Management Systems, Healthcare, Medical Records, etc., from several reliable sources. The second step is observing hospital services in several hospitals in some cities in Indonesia (Bandung, Cimahi, Solo, Yogyakarta, Klaten). The third step is conducting interviews to selected stakeholders of the healthcare systems. The interviews are using open questions and the stakeholder being interviewed are software house specializing in applications for Puskesmas, their applications are already used by about 300 Puskesmas in Central Java and Special Region of Yogyakarta, IT Department of Private Hospital in Special Region of Yogyakarta, researchers specializing in medical informatics from renowned private university in Yogyakarta, and medical practitioners / doctors. The last step is formulating proposed model for the integration of Medical Record Systems based on the current advances in Information Technology. The result and analysis of the findings are presented in the following section. 


\section{RESULT AND ANALYSIS}

\subsection{OBSERVATION OF HOSPITALS / MEDICAL FACILITIES}

Observations of hospitals have been conducted in several cities in Indonesia such as in Yogyakarta, Surakarta, Klaten, Cimahi, and Bandung. There are several observations:

1. Some modern hospitals in these cities already implement the Hospital Information System and electronic medical records. Since there is no regulation regarding electronic medical records, these hospitals implementing their own versions of electronic medical records to support their own needs.

2. Some hospitals are implementing minimal versions of Hospital Information System, such as the system provided by BPJS (Regulating Board for Social Security).

3. Hospitals in the same holding group (under the same franchise or the same foundations) may have different Hospital Information Systems that may or may not communicate with each other.

4. Patient transfer from one hospital to another is based on a medical record resume which is printed-based. Exceptions for patients supported by BPJS already have forms of electronic data transfer of medical records supported by the board.

5. Hospitals are obligated to send data about patients to the Ministry of Health in the form of summarized data and not in detailed patient's data.

6. Puskesmas / Centre of Community Health is obligated to use paper-based medical records and keep them for at least 10 years. These Puskesmas are also using medical information system provided by several vendors. The format of the electronic medical records is not standardized and based on the requirement from Dinas Kesehatan or the Department of Health in the Districts which is different format from one department to another.

\subsection{STANDARDS FOR MEDICAL RECORDS}

Medical Records based on Hicks [16] should consist of 6 parts which are personal identification information, medical history, family medical history, medication history, treatment history, and medical directives. Personal identification information should consist of personal identification and facility-specific information. Medical history consists of all diagnosis, medical care, treatments, allergies, and lack of need for medical care. The family medical history should consist of genetic markers and family history of physicians. Medication history should consist of prescribed, over the counter, herbal, and illegal. Treatment history should detail about treatment given whether is working or not working. Finally, medical directives should consist of medical directives or living will.

There are some International Standards that regulate the medical records and the interchange of data for medical facilities. The first standard is HL7 which evolves from HL7 to HL7 v2, HL7 v3 and HL7 FHIR [17]. The HL7 FHIR already accommodates modern electronics formats such as OAUTH2 Authentication and JSON / XML format [18]. The second standard is SOAP notes [19] which regulates how to write medical notes which have the format of Subjective, Objectives, Assessment, and Plan. Subjective describes patient description and complaints, primary complaints and other related notes. The Objectives parts should record everything that can be measured which should be nonbiased such as medications, allergies, past medical histories, past surgical histories, family histories, social histories, vitals, and physical examination. Assessment parts should describe the relation of symptoms to finding and the goals. The plan describes how to reach their goals. The third standard is DHIS2 (District Health Information Software 2) [20] 
which is the free and open-source health management data platform. DHIS will act as the Datawarehouse to integrate data from different location. In Indonesia there is implementation of DHIS2 which is in https://data.kemkes.go.id.

\subsection{GAPS OF OBSERVATIONS TO STANDARDS}

All medical facilities are obligated to submit reports periodically to the Ministry of Health and its branches in the provinces and districts are, but the standard format for the report is never specified and the reports are mostly aggregate data. The format of the reports that must be submitted from Puskesmas to the Ministry of Health is not standardized and mostly still in spreadsheet-based. The Puskesmas' are also obligated to keep the printed record of medical records for at least 10 years and there is no regulation regarding electronic Medical Records format for this medical facility. The role of the Centre of Information and Data (Pusdatin) at the Ministry of Health is also not yet optimized.

On the contrary, the healthcare conditions in Indonesia is still far from ideal. The medical education for general practitioners and specialist are very expensive. Access for healthcare services in rural areas is still limited.

\subsection{PROPOSED SOLUTIONS}

The suggested model of the integration of medical record systems shall consist of several components. The first component is the Medical Centre Server at the Ministry of Health. The second component is Authentication Server at Ministry of Internal Affairs. These two servers will serve all the Medical Facilities such as Hospitals, Clinics / Puskesmas, and Private Clinics / Other Stakeholders. Figure 1 shows the proposed arrangement of the integrated medical record systems.

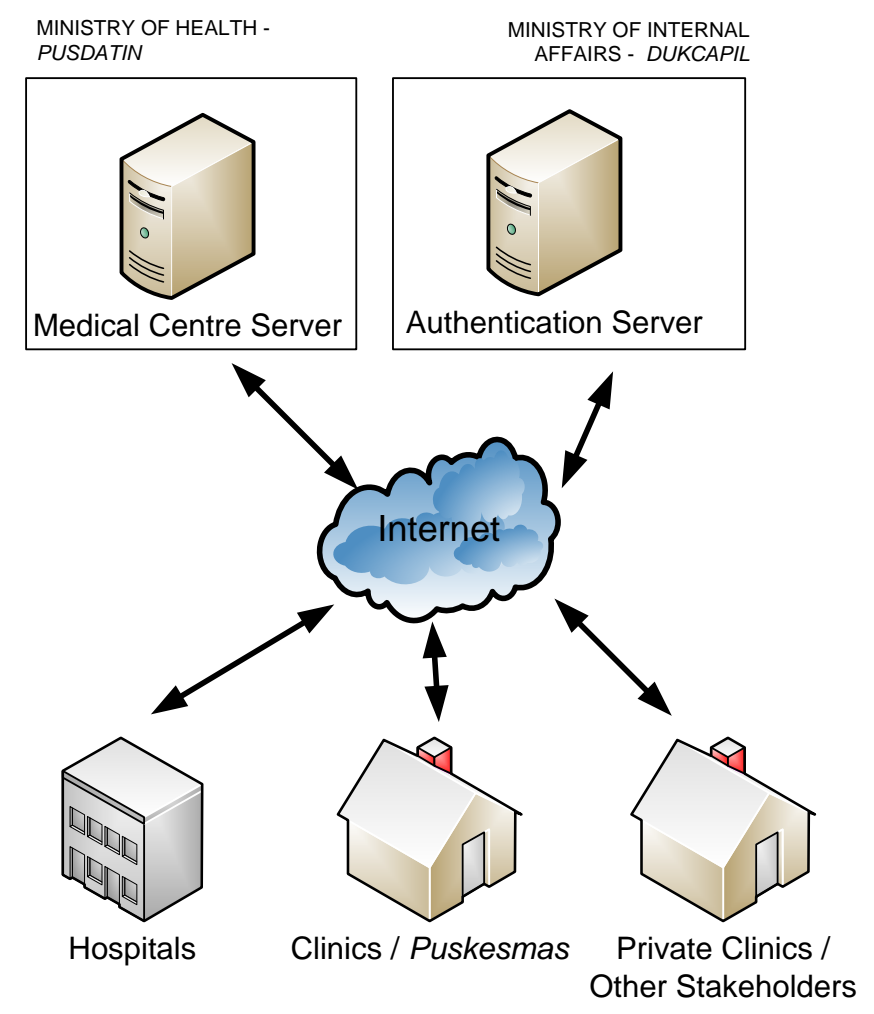

Fig. 1 Proposed Architecture for Integrated Medical Record System

There shall be a centralized medical record which is called Medical Centre Server which is located at the Ministry of Health (especially Pusdatin) to integrate all the medical records 
from all hospitals and medical facilities in Indonesia. Each of the hospitals / medical facilities will use their existing format of the medical records with minor modifications such as the inclusion of NIK (Nomor Induk Kependudukan) to give each patient's unique identity number. The medical facilities should be obligated to submit the summary of all their patient's medical records periodically to this central server. The medical facilities also may get the medical record summary from this central server based on the patient's NIK. The Ministry of Internal Affairs (especially Dukcapil) will act as the authentication server for the two-way communications between the Medical Centre Server and hospitals / other medical facilities / Puskesmas. The following is the detail of each of the components in Figure 1.

4.4.1. MEDICAL CENTRE SERVER AT MINISTRY OF HEALTH: There should be several technologies and services implemented in the Medical Centre Server. This Medical Centre Server shall be based on NoSQL Document Management System so it will accept any kinds of data sent from hospitals / medical clinics / Puskesmas with the NIK (Nomor Induk Kependudukan) used as the "primary key" of the integrated records for each individual. All of the data should be recorded in the BSON format in NoSQL and the identity of each patient can be recognized by his / her NIK. The Medical Centre Server should also facilitate sending data to hospitals / medical clinics / Puskesmas by using REST API protocols.

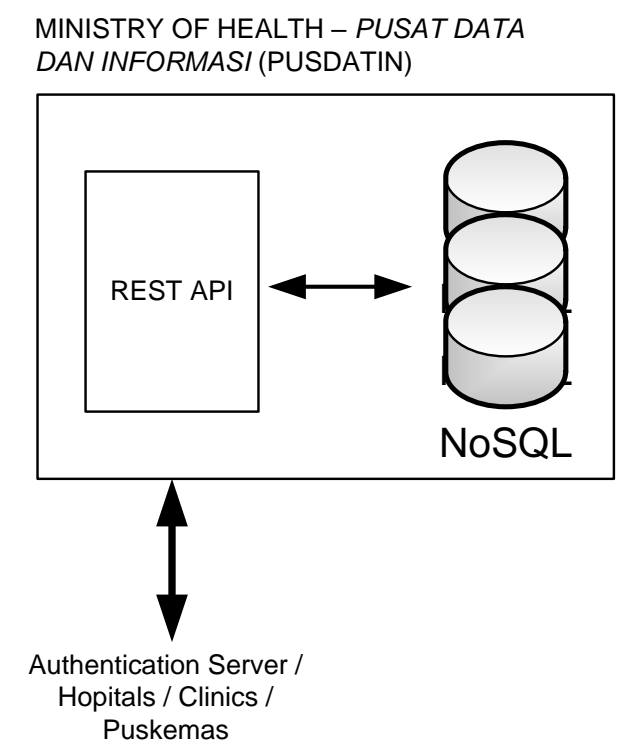

Fig. 2 Proposed Medical Centre Server at PUSDATIN

4.4.2. AUTHENTICATION SERVER AT MINISTRY OF INTERNAL AFFAIRS: An authentication system shall be set up by using OAUTH2 server in the Ministry of Internal Affairs (Kementrian Dalam Negeri especially in Dukcapil / Department of Population and Civil Registration department). The data interchange, especially the request of patient's medical records should be authenticated with this server. The sending of new medical records to the Medical Centre Server also shall be authenticated with this server. 


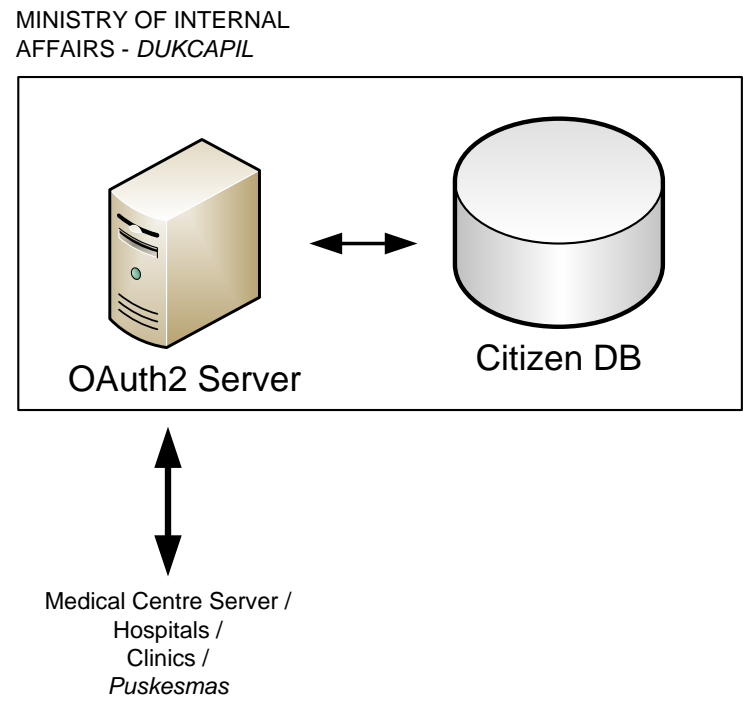

Fig. 3 Proposed Authentication Server at DUKCAPIL

4.4.3. HOSPITALS: Hospitals should modify their system to be able to communicate to the Medical Centre Server. There are some scenarios based on the types of hospitals:

- Government-owned Hospitals: Government-owned Hospitals may be regulated by the Ministry of Health to modify their Hospital Information System to submit the patient's medical records in specific format to be submitted to Medical Centre Server. The HIS also should be able to retrieve patient's medical record data from the Medical Centre Server.

- Hospitals with Franchises: All the franchisees using identical Hospital Management System. Synchronization of data such as medical records among all of the franchisees may be performed using SymmetricDB [15]. The medical record should be submitted periodically by the main franchisee to the Medical Centre Server with the authentication service from Authentication Server.

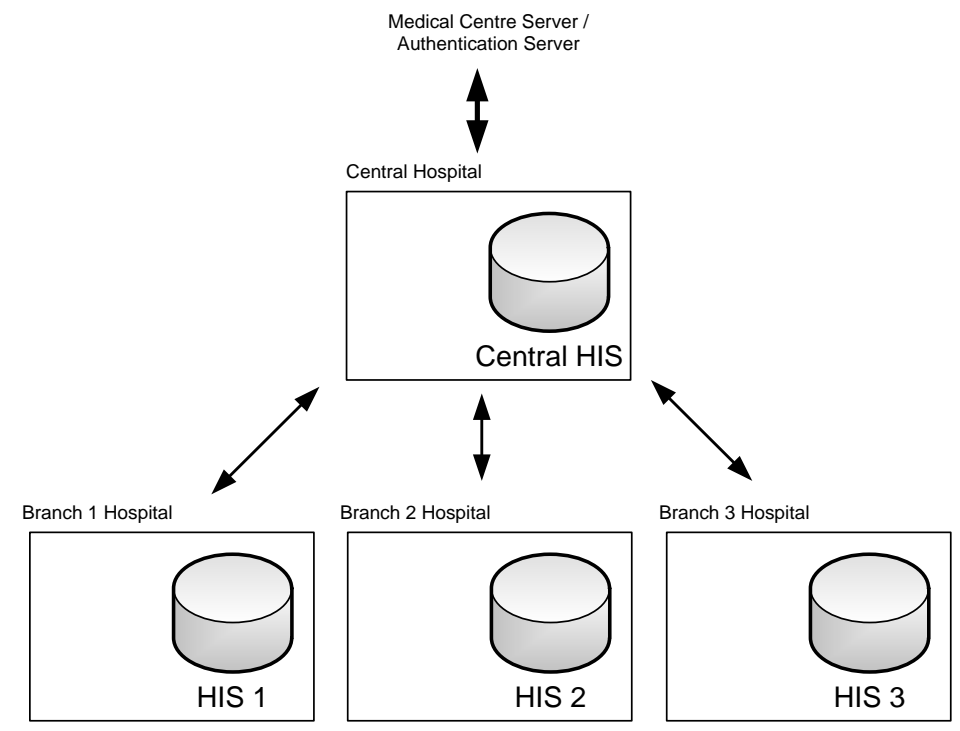

Fig. 4 Arrangement for Hospitals with Franchises

- Independent Hospitals: Independent hospitals shall have their own Hospital Information System. The HIS should be configured to send data to the Medical 
Centre Server periodically. The HIS should also able to request medical records history about certain patients from the server. These hospitals must be able to receive transfer of patients from other hospitals, Puskesmas, or clinics. These hospitals also should be able to transfer patients to other hospitals in case further services are required.

4.4.4. MEDICAL CLINICS AND PUSKESMAS: Medical Clinics shall have their own Clinics Information System. The CIS should be configured to send data to the Medical Centre Server periodically. The CIS should also able to request medical records history about certain patients from central server. This clinic must be able to receive transfer of patients from Puskesmas, or other clinics. These clinics also should be able to transfer patients to hospitals in case further services are required. Puskesmas should have their own Puskesmas Information System. The PIS should be configured to send data to Medical Centre Server periodically. The PIS should also able to request medical records history about certain patients from central server. This Puskesmas must be able to receive transfer of patients from other Puskesmas, or clinics. These Puskesmas also should be able to transfer patients to hospitals in case further services are required.

4.4.5. OTHER CLINICS AND STAKEHOLDERS: Private Medical Practises: Private medical practices shall have their own Information System. The IS should be configured to send data to the Medical Centre Server periodically. The IS should also able to request medical records history about certain patients from central server. These practices also should be able to transfer patients to hospitals in case further services are required. Other stakeholders that should also be integrated into the Medical Centre Server such as BPJS and other insurance companies, pharmacies, etc. The implementation shall also consider Indonesia's local wisdom regarding healthcare, which are: Pos Yandu (community health services for children under 5 and pregnant women), alternative and traditional medication, and jamu (Indonesia's herb medication).

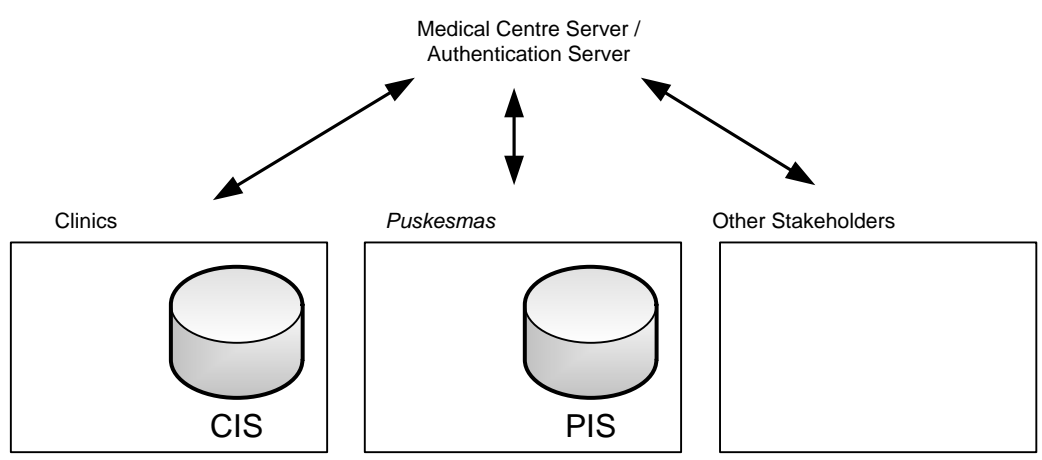

Fig. 5 Proposed Arrangement for Clinics, Puskesmas, and Other Stakeholders

\subsection{PHASES OF IMPLEMENTATIONS}

The implementation of the proposed architecture will take time. The phases of implementations:

4.5.1. GOVERNMENT-OWNED HOSPITALS: government-owned Hospitals should the first types of hospitals to be integrated. These hospitals are easier to be regulated by the Ministry of Health due to the nature of the ownership by the government. This may also provide pilot project for the integration of the Medical Records. 
4.5.2. HOSPITALS WITH FRACHISES: Hospitals with franchises should be integrated into the second phase. The similarity of the Hospital Information system in a similar franchise will make it easier to integrate the electronic Medical Records.

4.5.3. INDEPENDENT HOSPITALS: Independent Hospitals: Independent hospitals should be integrated into the third phase. The modifications of the Hospital Information System should be done to enable integration.

4.5.4. CLINICS / PUSKESMAS: Clinics and Puskesmas should be integrated into the fourth phase. Puskesmas / Clinics that not yet implement Information System should be modernized, and other Clinics / Puskesmas that already implement PIS / CIS may need some modification to enable integration of the electronic Medical Records.

4.5.5. OTHER STAKEHOLDERS: other stakeholders should be integrated into the system. These stakeholders may include Pharmacies, and other local wisdom in Indonesia such as Јати (Indonesia Herbal Medication), and other certified alternative medications.

\section{CONCLUSION}

Indonesia, a country with the $4^{\text {th }}$ largest population in the world and area scattered in 17,000 islands poses challenges in providing healthcare. The lack of standardization regarding the electronic version of Medical Records also provides additional challenges in providing effective health support. In the current progress of technology, it can be shown that integrating medical records from many different formats is feasible through the current advances in technology. These technologies include database replication systems such as SymmetricDS, REST API, NoSQL, OAUTH2, etc.

The implementation of the integration cannot be conducted simultaneously, there should be phases. The first phase is the integration of government-owned hospitals. The second phase is the integration of other medical facilities owned by government. The third phase is the integration from franchise or grouped hospitals. The fourth phase is the integration from independent hospitals. The last phase is the integration of other remaining medical facilities.

\section{REFERENCES}

[1] Kementrian Kesehatan Republik Indonesia, "Tugas dan Fungsi," 13 July 2014. [Online]. Available: http://www.depkes.go.id/article/view/13010100003/struktur-organisasi-kementerian-kesehatanrepublik-indonesia.html. [Accessed 4 April 2018].

[2] N. Mboi, "Indonesia: On the Way to Universal Health Care," Health Systems and Reforms, vol. 1:2, no. Taylor \& Francis, DOI: 10.1080/23288604.2015.1020642, pp. 91 - 97, 2015.

[3] Sardjito Media, "Banyak Rumah Sakit Belum Terapkan Rekam Medis Integrasi," 14 September 2018. [Online]. Available: https://indonesiana.tempo.co/read/127636/2018/09/14/sardjitomedia/banyakrumah-sakit-belum-terapkan-rekam-medis-integrasi. [Accessed 110 2019].

[4] B. E. Purnama and A. Ashari, "Distributed Data Patient in Medical Record Information System," International Journal of Scientific dan Technology Research, vol. 2, no. 8, pp. 116 - 122, 2013.

[5] E. Hariana, G. Y. Sanjaya, A. R. Rahmanti, B. Murtiningsih and E. Nugroho, "Penggunaan Sistem Informasi Manajemen Rumah Sakit (SIMRS) di DIY," in Seminar Nasional Sistem Informasi Indonesia 2013, Surabaya, 2013.

[6] A. B. Saputra, "Identifikasi Faktor - Faktor Keberhasilan Implementasi Sistem Informasi Manajemen Rumah Sakit," Jurnal Penelitian Pers dan Komunikasi Pembangunan, vol. 19, no. 3, pp. 135 - 148, 2016.

[7] M. Y. Ricky, "Analisis dan Perancangan Sistem Informasi Laboratorium Rumah Sakit," Comtech, vol. 1, no. 2, pp. 561 - 574, 2010.

[8] M. F. Pataha, G. Y. Sanjaya and L. Trisnantoro, "Penggunaan Open Source Software (OSS) di Rumah Sakit," Jurnal Informatika, vol. 8, no. 2, pp. 933 - 942, 2014.

[9] R. Retnowati and A. Pujiyanta, "Implementasi Case Based Reasoning pada Sistem Pakar dalam Menentukan Jenis Gangguan Kejiwaan," Jurnal Sarjana Teknik Informatika, vol. 1, no. 1, pp. 69 - 78, 2013. 
[10] E. Buulolo, "Implementasi Algoritma Apriori pada Sistem Persediaan Obat (Studi Kasus: Apotik Rumah Sakit Estomihi Medan)," Pelita Informatika Budi Darma, vol. 4, no. 1, pp. 71 - 83, 2013.

[11] H. Antonius and E. Widjaja, "Data Warehouse pada Rumah Sakit," in Seminar Nasional Aplikasi Teknologi Informasi (SNATI) 2010, Yogyakarta, 2010.

[12] W. Kaswidjanti, H. Sofyan and L. Hawari, "Aplikasi e-CRM Berbasis Web pada Rumah Sakit," TELEMATIKA, vol. 8, no. 1, pp. 17 - 24, 2011.

[13] Y. B. Hege, U. Lestari and E. Kumalasari, "Sistem Informasi Geografis (SIG) Pelayanan Kesehatan di Kotamadya Yogyakarta Berbasis Web," Jurnal SCRIPT, vol. 1, no. 2, 2014.

[14] J. Braa, S. Sahay, J. Lewis and W. Senyoni, "Health Information Systems in Indonesia: Understanding and Addressing Complexity," IFIP International Federation for Information Processing, no. ICT4D 2017, IFIP AICT 504, DOI: 10.1007/978-3-319-59111-7_6, pp. 59 - 70, 2017.

[15] A. W. Emanuel, T. L. Wargasetia and A. K. Surawijaya, "Sinkronisasi Pangkalan Data Rumah Sakit dengan Aplikasi Open Source SymmetricDS," JuTISI, Vols. Vol. 3, No. 3, 2017.

[16] J. Hicks, "The Basic Components of a Complete Medical Record," 28 March 2019. [Online]. Available: https://www.verywellhealth.com/importants-parts-of-a-medical-record-2317249. [Accessed 7 January 2019].

[17] R. H. Dolin, L. Alschuler, C. Beebe, P. V. Biron, S. L. Boyer, D. Essin, E. Kimber, T. Lincoln and J. E. Mattison, "The HL7 Clinical Document Architecture," J Am Med Inform Assoc (JAMIA), vol. 8, pp. 552 $-569,2001$.

[18] D. Bender and K. Sartipi, "HL7 FHIR: An Agile and RESTful Approach to Healthcare Information Exchange," in The IEEE Symposium on Computer-Based Medical Systems , June 2013.

[19] Gap Medics, "What is SOAP Note?," 2 Januari 2015. [Online]. Available: https://www.gapmedics.com/blog/2015/01/02/understanding-soap-format-for-clinical-rounds/. [Accessed 30 May 2019].

[20] UiO: Department of Informatics, "Health Information Systems Programme (HISP)," 17 March 2011. [Online]. Available: https://www.mn.uio.no/ifi/english/research/networks/hisp/. [Accessed 30 May 2019]. 